\title{
The prescience to measure airway reactivity in horses without heaves
}

\author{
A. M. Hoffman \\ Tufts University School of Veterinary Medicine, North Grafton
}

\begin{abstract}
Summary
Horses that exhibit reduced aerobic performance, mucus in the airways, and/or cough have long been discussed as a subgroup of COPD or more recently, 'inflammatory airway disease (IAD)'. Many highly aerobic horses such as racehorses and eventers with IAD, have no clinical signs at all other than a decline in performance. Hence more sensitive, objective tests for diagnosis are required. Highlighted here is a paper published by Klein and Deegen that demonstrated, way ahead of its time, the clinical utility of measuring airway responses to aerosolized histamine (non-specific airway reactivity). Although others before had applied the method in research involving horses with heaves, Klein and Deegen had the foresight to apply this method to the clinical population without heaves, presumably with IAD. Recent data has shown that horses with IAD (based on bronchoalveolar lavage cytology) have extremely high levels of airway reactivity to histamine. The test of airway reactivity, first reported in non-heaves horses by Klein and Deegen, will be an important diagnostic tool in the assessment of low-grade respiratory signs and poor performance in the future.
\end{abstract}

Keywords: airway reactivity, inflammatory airway disease, IAD, COPD, heaves, poor performance, cough.

\section{Zur Messung der Atemwegs-Reaktivität bei COB-freien Pferden}

Pferde mit verminderter aerober Leistung, mit Mukus in den Atemwegen und/oder Husten wurden bisher als eine Untergruppe der COPD oder neverdings der IAD (Inflammatory airway disease) angesehen. Viele typisch aerobe Pferde, wie Renn- oder Vielseitigkeitspferde, mit IAD zeigen außer verminderter Leistungsfähigkeit keinerlei andere klinische Anzeichen. Um die Erkrankung sicher diagnostizieren zu können, sind deshalb empfindlichere und objetive Tests nötig. In diesem Zusammenhang ist eine richtungweisende Veröffentlichung von Klein und Deegen zu nennen, die schon früh den klinisch-diagnostischen Wert der Messung der unspezifischen Atemwegsreaktivität auf vernebeltes Histamin durch den Histamin-Provokationstest aufgezeigt haben. Zwar wandten auch andere Autoren diese Methode bei Forschungen an Pferden mit chronischer Bronchialobstruktion und deutlicher Atembeschwerde an, Klein und Deegen besaßen jedoch die Weitsicht, die Anwendung der Methode auch auf Pferde ohne klinisch auffällige Dyspnoe aber mit Anzeichen einer IAD auszudehnen. Neuere Untersuchungen haben gezeigt, dass Pferde mit durch BAL-Zyłologie nachgewiesener IAD extrem erhöhte Histamin-Reaktivität aufweisen. Der Histamin-Provokationstest, der erstmals von Klein und Deegen bei lungenkranken Pferden angewandt worden war, die klinisch keine Dyspnoe zeigten, wird sich in Zukunft als wichtiges diagnostisches Instrument zur Erkennung geringgradiger Atemwegsbefunde und damit in Zusammenhang stehender Leistungsminderung erweisen.

Schlüsselwörter: Atemwegsreakitivität, IAD, COB, COPD, Leistungsminderung, Husten, Histamin-Provokationstest

A landmark research paper was published by Klein and Deegen in 1986 entitled "Histamine inhalation provocation test: Method to identify nonspecific airway reactivity in equids. The paper made little 'splash' in the lay press, nor was there an abundance of scholarly commentary in response. It seemed that, like many German papers, it went disturbingly unnoticed in the USA. At the time, I began working as a Large Animal Medicine Resident and Graduate Student at the University of Guelph in Ontario, Canada, fresh out of private practice. There, Dr. Laurent Viel was meticulously cataloguing the bronchoalveolar lavage (BAL) cytology of horses with poor performance, and I was fortunate to join his group. We principally saw racehorses, and the common complaint was 'fading at the $\mathrm{fl}$ mile mark.' Viel seemed to me to be one of the only persons, that was really enthusiastic about low-grade airways inflammation in horses without heaves (Fogarty and Buckley 1991). Indeed, there was no name for this condition in English, so we and others (Moore et al 1997) made them up: small airway disease, small airway inflammatory disease, and inflammatory airway disease. Viel (1997) hypothesized that the cytologic inflammation portended airway obstruction, and the latter was the cause of poor performance. Klein and Deegen's paper was crucial evidence, but the proof of concept would not come for years. Klein and Deegen appeared to have sensed the need to address problems in their clinical caseload by using more objective tests. Conventional testing using esophageal pressure - flow data does not detect abnormalities in non-heaves horses (Sasse 1973, Hoffman 2002) so a different approach was needed. Klein and Deegen were persistent, and followed their hunch that something was functionally deranged in these milder cases. Many of the horses had remarkable mucus accumulations visible by endoscopy, the latter technique being rather new. They proposed a challenge test analogous to methacholine challenge in humans suspected with asthma.

Anyone that has performed lung function test in equine outpatients knows that it poses several challenges. Equine patients are unaccustomed to the lung function testing equip- 
ment, clinic, and handlers. The black and white photo accompanying the paper attested to these difficulties, i.e. horses were placed in stocks, with a strap over their back, crossties, and were instrumented with a tight fitting facemask, an esophageal balloon catheter, nebulizer, and pneumotachograph, all sources of intimidation. Short term ( $<15 \mathrm{~min}$ ) lung mechanics are typically met with grace and cooperation by horses, but longer testing periods (>1 hr) necessary for histamine challenges can provoke significant anxiety. The investigators were clearly not 'faint of heart'. Airway reactivity in horses in varying stages of respiratory disease, including a heaves and a non-heaves group, was compared to airway reactivity in controls. The non-heaves group of interest had "low-grade respiratory disease", defined by mucus on endoscopy, normal arterial $\mathrm{O}_{2}$ concentrations, in addition to some with audible wheezes provoked during lobeline induced hyperpnea. This group represented a highly prevalent sector of respiratory disease that was underrepresented in the scientific literature. An important finding, and one that they underemphasized in my opinion, was a "minimally significant $(\mathrm{P}<0.05)^{\prime \prime}$ increase in airway reactivity to histamine in horses. If one examines the mean, the differences were indeed small, but some of the 21 non-heaves respiratory disease horses (25\% according to the authors) had marked airway hyperreactivity. It was a vital clue, and the first time that any lung dysfunction per se was demonstrated in horses without heaves, and that horses without clinical signs of increased respiratory effort, differed with respect to lung function yet retained normal gas exchange at rest. The results also suggested that heaves may arise from an earlier form of disease, based on a common thread - airway hyper-reactivity, although the authors wisely avoided this speculation.

Distance, time, language barriers, skepticism about the relevance of clinical research, lack of duplication, and the perception that "Germans horses are different", may have contributed to the fact that functional studies in non-heaves horses languished over the next decade. Results from a prolific research group may have unintentionally overshadowed Klein and Deegen's conclusions as well. Derksen et al (1985a, 1985b) and Armstrong et al (1986) published papers demonstrating a marked increase in airway reactivity after mold hay challenge in heaves susceptible ponies. It was assumed thereafter, that airway reactivity returned to 'normal' after pasturing. These findings in may have inadvertently relegated airway reactivity to a research, rather than a clinical tool, as intended by Klein and Deegen.

The diagnostic value of testing airway reactivity in horses may have been lost, if it were not for the persistence of clinicianscientists. Doucet (1991) picked up where Klein and Deegen left off, with a study in 1991 that demonstrated again, that horses without heaves, yet mild respiratory signs indicative of airway inflammation, possessed airway hyper-reactivity relative to controls. Again, the significance of this research was largely overlooked, except by Viel. He knew that this kind of data breathed life into his cytologic findings. From 1995 1998, at Tufts University, we decided to pursue more evidence, convinced that horses with signs of IAD possessed a measurable disturbance. We developed an alternative method of testing airway reactivity based on oscillometry (Young et al. 1989, Young und Tesarowski 1994, Hoffman 1997, Hoffman et al. 1998, Hoffman 1999, Mazan et al. 1999), but the con- cept of provoking the airways with nebulized histamine, and the doses and intervals used, arose from Klein and Deegen's paper. Our method was non-invasive, and we chose to sedate our horses, both of which facilitated more large-scale testing in outpatients, while provoking less anxiety in the owners. Our studies differed from Klein and Deegen in that 1) we did not challenge horses with heaves in crisis, only in remission, and 2) we grouped the horses based on clinical and cytologic grounds (control, IAD with abnormal BAL, and heaves - horses with a history of heaves and an abnormal $\mathrm{BAL}$ ). This eliminated horses with cough or poor performance that lacked lower airway inflammation from the IAD group. The results we found were statistically even more dramatic. Horses with IAD had substantially greater airway reactivity than controls without airway inflammation, but the severity of airway hyper-reactivity was similar to that of heaves in remission (Hoffman 1999). We also observed a large distribution of non-specific airway reactivity in clinical cases of IAD. Furthermore, we confirmed Klein and Deegen's finding of a lack of association between baseline indices of airway obstruction (pulmonary resistance, dynamic compliance) and airway reactivity, following the pattern established in human asthma. In contrast, cytological findings correlated well with airway reactivity. Specifically, the mast cell percentage of BAL fluid correlated reasonably well $(r=0.74, \mathrm{P}<0.001)$ with airway reactivity in young horses with cough and/or exercise intolerance (Hoffman et al. 1998, Hoffman 1999). This data furthered the notion by Viel (1997) that abnormal BAL cytology typified by mast cell infiltration into airways in horses with signs of IAD was an indication of a functional disturbance, that could explain cough and poor performance. Airway response to histamine, as suggested in 1986 by Klein and Deegen and later Doucet et al. (1991) and us (Hoffman 1997), was not only a "method to identify non-specific airway hyper-reactivity in equids" but suggested that airway inflammation, possibly of allergic origin, was linked to a functional disturbance. There were more indications that this condition resembled asthma, according to the authors.

Basic questions about airway hyper-reactivity remain. First, we do not know the pathogenesis. To what extent does airway hyper-reactivity have a structural basis versus inflammatory mediator driven effect? Do horses with heaves tone down their airway reactivity to 'normal' levels with the extreme measures of $24 \mathrm{hr} /$ day pasturing, or do they return to an abnormal baseline? The prevailing theory in 1986 was that pulmonary dysfunction (resistance, compliance, pleural pressure changes) was completely reversible in horses with heaves due to pasturing (Thomson and McPherson 1984). Klein and Deegen opened the door for a more sensitive test that challenged that concept. Our data of airway reactivity in heaves horses in remission clearly shows that airway hyper-reactivity may coexist with clinical remission. Is airway hyper-reactivity a phenotype that is out of the realm of environmental or therapeutic control? Vandenput et al. (1998) stabled heaves susceptible horses in a clean environment lacking hay or straw, and saw a rise in airway reactivity without signs of heaves. Control is therefore a more complex and challenging procedure than pasturing, and even normal horses can experience inflammation in the stable. The test of airway reactivity should be incorporated in future studies of the epidemiology of lower respiratory disease in horses, since it is more sensitive to the inflammatory status of the airways. 
Banking on the importance of airway reactivity to the diagnosis and study of IAD, we have focused our energies on the development of a non-invasive portable version of the histamine challenge test based on plethysmography (Hoffman et al. 2001) that can be directly traced to Klein and Deegen's paper. The aim is to provide the practitioner and clinical researcher with a tool to recognize and confirm the presence of airway hyper-reactivity in the field, without the technical difficulties associated with clinical testing (Kuehn et al. 2000). We predict that the provocation test, first performed in naturally occurring clinical cases by Klein and Deegen, will become a mainstay in diagnostic testing of horses with low-grade clinical signs of respiratory disease (Hoffman 2001). Their foresight deserves recognition and we thank them. Professor Deegen was clearly ahead of his time in stewarding along this discovery. This experience has further taught us that greater exchange of information with German veterinary scientists concerning equine health issues is vital. After all, German horses are not really different, just better looking.

\section{Literature}

Armstrong P. J., Derksen F. J., Slocombe R. F. nd Robinson N. E. (1986): Airway responses to aerosolized methacholine and citric acid in ponies with recurrent airway obstruction (heaves). Am Rev Respir Dis 133, 357-361

Derksen F. J., Robinson N. E., Armstrong P. J., Stick J. A. und Slocombe R. F. (1985a): Airway reactivity in ponies with recurrent airway obstruction (heaves). J Appl Physiol 58, 598-604

Derksen F. J., Scott D., Robinson N. E., Slocombe R. F. und Armstrong P.J. (1985b): Intravenous histamine administration in ponies with recurrent airway obstruction (heaves). Am J Vet Res 46, 774-777

Doucet M. Y., Vrins A. A. und Ford-Hutchinson A. W. (1991): Histamine inhalation challenge in normal horses and in horses with small airway disease. Can J Vet Res 55, 285-293

Fogarty U. und Buckley T. (1991): Bronchoalveolar lavage findings in horses with exercise intolerance. Equine Vet J 23, 434-437

Hoffman A. M. (1997): Outpatient lung function testing and the use of inhaled medications. Proceedings of the Second Dubai International Equine Symposium - Diagnosis and Treatment of Respiratory Diseases, Dubai, UAE, 299-313

Hoffman A. M. (1999): Programme of lung function testing horses with suspected small airway disease. Equine Vet Educ 11, 322328

Hoffman A. M. (2001): Respiratory applications for the future: one perspective. Vet Clin N Amer-Equine Pract Edition 17, 335-349

Hoffman A. M., Riedelberger K., Kupcinskas R. und Miscovic M. (2001): Flow-metric comparison of respiratory inductance plethysmography and pneumotachography in horses. J Appl Physiol 91, 2767-2775
Hoffman A. M. (1999): Bronchoalveolar lavage technique and cytologic diagnosis of small airway inflammatory disease. Equine Vet Educ 1 1, 330-336

Hoffman A. M. (2002): In: Equine Respiratory Diseases, P. Lekeux (Ed.) "Clinical Application of Pulmonary Function Testing in Horses". International Veterinary Information Service (wwwivisorg)

Hoffman A. M., Mazan M. R. und Ellenberg S. (1998): Association between bronchoalveolar lavage cytologic features and airway reactivity in horses with a history of exercise intolerance. Am J Vet Res 59, 176-181

Klein H. J. und Deegen E. (1986): Histamine inhalation provocation test: method to identify nonspecific airway reactivity in equids. Am J Vet Res 47; 1796-1800

Kuehn H., Bolton B., Bruns S., Swanson L. und Hoffman A. (2000): Repeatability of a largeanimal flowetric system (LAFS) for testing airway reactivity in the field. Proceedings of the Proc Comp Resp Soc, Melbourne, Australia, 56

Mazan M. R., Hoffman A. M. und Manjerovic N. (1999): Comparison of forced oscillation with the conventional method for histamine bronchoprovocation testing in horses. Am J Vet Res 60, 174 180

Moore B. R., Krakowka S., McVey D. S., Cummins J. M. und Robertson J.T. (1997): Inflammatory markers in bronchoalveolar lavage fluid of standardbred racehorses with inflammatory airway disease: response to interferon-alpha. Equine Vet J 29, 142-147

Sasse H. H. H. (1973): [Pulmonary function in the horse]. Tierarztl Prax 1, 49-59

Thomson J. R. und McPherson E. A. (1984): Effects of environmental control on pulmonary function of horses affected with chronic obstructive pulmonary disease. Equine Vet J 16, 35-38

Vandenput S., Votion D., Duvivier D. H., Van Erck E., Anciaux N,. Art T. und Lekeux P. (1998): Effect of a set stabled environmental control on pulmonary function and airway reactivity of COPD affected horses. Vet J 155, 189-195

Viel L. (1997): Small airway disease as a vanguard for chronic obstructive pulmonary disease. Vet Clin North Am Equine Pract $13,549-560$

Young S. S. und Hall L. W. (1989): A rapid, non-invasive method for measuring total respiratory impedance in the horse. Equine Vet $J$ 21, 99-105

Young S. S. und Tesarowski D. (1994): Respiratory mechanics of horses measured by conventional and forced oscillation techniques. J Appl Physiol 76, 2467-2472

Andrew M. Hoffman

Tufts University School of Veterinary Medicine

200 Westboro Rd,

North Grafton, MA, 01536

andrew.hoffman@tufts.edu 